\title{
Non-alcoholic fatty liver disease in obese children and co-existing liver diseases
}

\author{
Obez Çocuklarda Alkolik Olmayan Yağlı Karaciğer Hastalığı ve Eşlik \\ Eden Diğer Karaciğer Hastalıkları

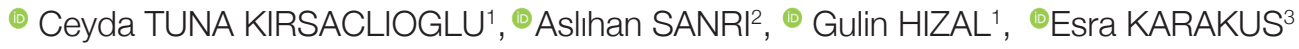

\footnotetext{
${ }^{1}$ Department of Pediatric Gastroenterology, Hepatology and Nutrition, Ankara Child Health Diseases, Haematology Oncology Training and Research Hospital, Ankara, Turkey

${ }^{2}$ Department of Pediatrics, Ankara Child Health Diseases, Haematology Oncology Training and Research Hospital, Ankara, Turkey

${ }^{3}$ Department of Pathology, Ankara Child Health Diseases, Haematology Oncology Training and Research Hospital, Ankara, Turkey.
}

\begin{abstract}
Objective: The prevalence of non-alcoholic fatty liver disease (NAFLD) in children increased parallel to the increment of childhood obesity. Also, NAFLD may be the presenting feature of different liver diseases in non-obese children. We aimed to determine whether there were co-existing liver diseases in overweight and obese children with NAFLD.

Material and Methods: Pediatric gastroenterology outpatient clinic records of obese and overweight patients, aged between 5-18 years, were retrospectively reviewed. Seventy patients who had liver steatosis on ultrasonography, and alanine aminotransferase (ALT) levels were higher than 1.5 times the upper limit of normal were recruited to the study. The demographic findings, laboratory tests for infectious, metabolic, and autoimmune causes, abdominal ultrasonography and liver biopsy findings of patients were recorded.

Results: At presentation, $94.2 \%$ of the patients ( $n: 66$ ) had mild transaminase elevation. All patients were negative for viral hepatitis, anti-tissue transglutaminase immunoglobulin (Ig) A, anti-liver-kidney-microsome type 1 and anti-smooth muscle antibody. They had normal erythrocyte sedimentation rate (ESR), C-reactive protein (CRP), ceruloplasmin, and total IgG levels. Only one patient with low alpha-1 antitrypsin levels had heterozygotes of the PiMZ phenotype. Three (4.3\%) patients had antinuclear antibody (ANA) positivity. $44.7 \%$ of patients were given ursodeoxycholic acid treatment. On follow-up, normalization of ALT was achieved in 31 (44.2\%) patients at mean 6.1 $\pm 4.6(2-19)$ months, but no relation was found between normalization and ursodeoxycholic acid treatment. A patient with ANA positivity had increased ALT, ESR, CRP, IgG levels and ANA titers on follow-up, and she was diagnosed with autoimmune hepatitis with the support of liver biopsy. Under prednisolone and azathioprine treatment, ESR and IgG levels were normalized, ALT and ANA titers decreased.
\end{abstract}

Conclusion: Other causes of chronic hepatitis should be screened in obesity-related non-alcoholic fatty liver disease and the development of autoimmune hepatitis should be kept in mind in the presence of ANA.

Key Words: Autoimmunity, Child, Non-alcoholic fatty liver disease, Obesity

\section{Öz}

Amaç: Çocuklarda obezitede artışa parallel olarak alkolik olmayan yağlı karaciğer hastalı̆̆ı (AOYKH) da giderek artmaktadır. Ancak obez olmayan çocuklarda, farkı karaciğer hastalıklarında da karaciğer yağlanması görülebilir. Bu çalışmada aşıı kilolu ve obez çocuklarda, AOYKH'ye eșlik edebilecek diğer karaciğer hastalıklarının belirlenmesi amaçlandı.

Gereç ve Yöntemler: Polikliniğimizde aşıı kilo ya da obezite ile izlenen, 5-18 yaş aralığındaki hastaların dosyaları geriye dönük tarandı. Ultrasonografide karaciğerde yağlanma ve normalin üst sınırından en az 1.5 kat kadar alanin transaminaz (ALT) yüksekliği olan 70 hasta çalısmaya alındı. Hastaların demografik verileri, enfeksiyöz, metabolik ve otoimmun nedenler için yapılan laboratuvar testleri, abdominal ultrasonografi ve karaciğer biyopsi bulguları kaydedildi.

Bulgular: Tanıda olguların \%94.2'ünde (66 olgu) hafif transaminaz yüksekliği vardı. Tanıda viral hepatit tarama, antidoku transglutaminaz immunglobulin (Ig) A, anti-liver-kidney-mikrozomal-1 ve anti-düz kas antikor negatifdi. Eritrosit sedimentasyon hızı (ESH), C-reaktif protein (CRP), total Ig G, seruloplazmin düzeyleri normaldi. Bir olguda alfa-1 antitripsin düzeyi düşüktü ve PiMZ fenotipi saptandı. Üç (\%4.3) olguda antinükleer antikor (ANA) pozitifliği saptandı. 


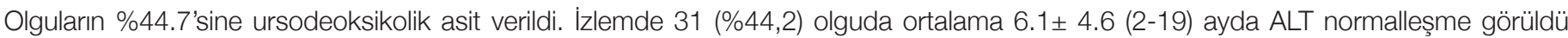
ancak ursodeoksikolik asit tedavisi ile ilişkisi saptanmadı. Tanıda ANA pozitif olan bir olguya izlemde ALT ve ANA titre düzeyi artması, eşlik eden IgG, ESH ve CRP yükselmesi nedeni ile karaciğer biyopsisi yapılarak otoimmun hepatit (OiH) tanısı konuldu, prednizolon ve azatiopürin tedavisi ile ALT düzeyinde ve ANA titresinde gerileme, ESR ve lgG'de normalleşme saptandı.

Sonuç: Obezite ile ilişkili alkolik olmayan yağlı karaciğer hastalı̆ında diğer kronik hepatit nedenleri taranmalı, ANA pozitifliğinde OiH gelişebileceği akılda tutulmalıdır

Anahtar Sözcükler: Otoimmun hepatit, Çocukluk çağı, Yağlı karaciğer hastalığı, Obezite

\section{OBJECTIVE}

Obesity is thought to be the main risk factor for pediatric nonalcoholic fatty liver disease (NAFLD). Nearly 38\%-80\% of overweight/obese children have NAFLD $(1,2)$. Though most of the children with NAFLD have a benign simple fatty liver disease, it may progress to cirrhosis $(2,3)$. Recently, North American Society of Pediatric Gastroenterology, Hepatology and Nutrition recommended the evaluation of children of obese/overweight children for other causes of chronic hepatitis if alanine aminotransferase (ALT) levels elevated $>3$ upper limits of normal (ULN) (4) In non-obese children NAFLD may be due to other causes of chronic hepatitis such as chronic hepatitis C, alpha-1 antitrypsin deficiency, Wilson's disease, autoimmune hepatitis $(4,5)$.

We aimed to determine the co-existing liver diseases in overweight and obese children with NAFLD.

\section{MATERIAL and METHODS}

In this retrospective study, we reviewed the medical records of overweight and obese children, admitted or referred to our pediatric gastroenterology outpatient clinic from January 2010 to December 2013. Seventy patients who had liver steatosis on ultrasonography and ALT levels were higher than 1.5 times the ULN were recruited to the study.

The demographic information, laboratory and abdominal ultrasonography and liver biopsy findings, treatment, and ALT levels on follow-up were recorded.

We calculated body mass index (BMI) as weight in kilograms divided by height in meters squared $\left(\mathrm{kg} / \mathrm{m}^{2}\right)$. According to age and gender charts of BMl from the World Health Organization (WHO), a BMl in the $\geq 85^{\text {th }}$ to $<95^{\text {th }}$ percentile is considered overweight, and a BMl in the $\geq 95^{\text {th }}$ percentile is considered obese (4).

Aspartate aminotransferase (AST), ALT, gamma-glutamyl transferase (GGT), alkaline phosphatase (ALP), total and direct bilirubin, creatine kinase, erythrocyte sedimentation rate (ESR), C-reactive protein (CRP), lipid profile, serologic markers for hepatitis A virus (HAV), hepatitis B virus (HBV), hepatitis $\mathrm{C}$ virus (HCV), Cytomegalovirus (CMV), Ebstein-Barr virus (EBV), Human immune deficiency virus (HIV), alpha-1 antitrypsin and ceruloplasmin levels, urinary copper excretion, total immunoglobulin (Ig) A, tissue transglutaminase IgA, total IgG, ANA, anti-liver-kidney microsome type 1 antibody (LKM1), anti-smooth muscle antibody (ASMA) were recorded. The patients were followed-up in 1-3 months period for ALT levels. Normal ranges of ALT and AST were 0-33 IU/L in our laboratory reference. All patients were given a diet and exercise programme.

The exclusion criteria were as the following; patients who had a previously known liver or muscle disease, patients with a single measurement of transaminase level, accompanied hyperbilirubinemia and patients who weren't screened for Wilson's disease, celiac disease, alpha-1 antitrypsin, viral causes, and autoimmunity.

According to the increment of transaminase levels, mild $(<$ 5x ULN), moderate (5-10x ULN), and severe (>10x ULN) hypertransaminasemia were defined.

Statistical analyses were performed using the Statistical Package for Social Sciences (SPSS) software 17.0. Results are presented as means \pm SDs with descriptive statistics. The Student's unpaired t-test and Mann Whitney $-U$ test was used as appropriate. The significance level was set at $p<0.05$.

\section{RESULTS}

Of the 70 patients, $49(70 \%)$ were males. The mean age was $11.8 \pm 3.8$ years. Sixty-seven (95.7\%) patients were obese and $3(4.3 \%)$ patients were overweight.

Three patients had a concomitant disease and medication. One patient was taking Na valproate for the epileptic disorder, the others were given in Table I. None of the patients had taking herbal medicine, recent infectious disease, blood transfusion, contact to a person with jaundice, tooth extraction. Of the patients, 15 had consanguinity between their parents.

At presentation, the mean value of ALT $[93.4 \pm 23.7$ (50-415) IU/I] was higher than AST [61.6 12.6 (27-227) IU/I] but it was not statistically significant. Most of the patients (n: 66, 94.2\%) had mild transaminase elevation.

Serologic markers for HAV, HBV, HCV, CMV, EBV, HIV, tissue transglutaminase $\lg \mathrm{A}$ were negative, total $\lg \mathrm{A}$, ceruloplasmin, creatine kinase levels, fasting glucose levels, thyroid function tests were in normal ranges in all patients. Urinary copper excretion was insignificant in 15/15 patients. 
Table I: The characteristics of patients with anti-nuclear antibody positivity at presentation.

\begin{tabular}{|c|c|c|c|}
\hline Gender & $\begin{array}{l}\text { Patient } 1 \\
\text { Female }\end{array}$ & $\begin{array}{l}\text { Patient } 2 \\
\text { Female }\end{array}$ & $\begin{array}{l}\text { Patient } 3 \\
\text { Female }\end{array}$ \\
\hline Age (years) & 10 & 8.5 & 16 \\
\hline Body mass index $\left(\mathrm{kg} / \mathrm{m}^{2}\right)$ & $27.2(>97 \%)$ & $20.1(95 \%)$ & $40(>97 \%)$ \\
\hline Accompanying disease & $\begin{array}{l}\text { Hashimoto thyroiditis, insulin } \\
\text { resistance }\end{array}$ & - & $\begin{array}{l}\text { Bardett-Biedel syndrome, } \\
\text { diabetes mellitus type } 2\end{array}$ \\
\hline Medication & L-thyroxine, metformin & - & Metformin \\
\hline Abdominal ultrasonography & $\begin{array}{l}\text { Grade 1-2 hepatosteatosis, } \\
\text { mild hepatomegaly }\end{array}$ & Grade 2 hepatosteatosis & $\begin{array}{c}\text { Grade } 2-3 \text { hepatosteatosis, } \\
\text { hepatomegaly. }\end{array}$ \\
\hline $\begin{array}{l}\text { Alanine transferase } \\
\text { (Normal ranges:0-33 IU/L) }\end{array}$ & 52 & 60 & 117 \\
\hline $\begin{array}{l}\text { Aspartate transferase } \\
\text { (Normal ranges:0-33 IU/L) }\end{array}$ & 32 & 48 & 73 \\
\hline Lipid profile & Normal & Normal & Normal \\
\hline Anti-nuclear antibody & $1 / 100(+)$ & $1 / 100(+)$ & $1 / 1000(+)$ \\
\hline
\end{tabular}

Table II: The characteristics of patients with anti-nuclear antibody positivity at time of biopsy, and follow up.

\begin{tabular}{|c|c|c|c|}
\hline & Patient 1 & Patient 2 & Patient 3 \\
\hline Time of biopsy after presentation (months) & 6 & 16 & 12 \\
\hline Alanine transferase (Normal range: 0-33 IU/I) & 53 & 108 & 157 \\
\hline Aspartate transferase (Normal range: 0-33 IU/I) & 69 & 38 & 191 \\
\hline Immunglobuline G (Normal range: 910- 1884 mg/dl) & 1170 & 1140 & 1980 \\
\hline Erythrocyte sedimentation rate $(0-20 \mathrm{~mm} / \mathrm{hour})$ & 19 & 12 & 57 \\
\hline C-reactive protein $(0-0.5 \mathrm{mg} / \mathrm{dl})$ & 0.3 & 0.1 & 1.5 \\
\hline Anti nuclear antibody & $1 / 100(+)$ & $1 / 100(+)$ & $1 / 1000(+)$ \\
\hline Non-alcoholic steatohepatitis score & $5 / 8$ & $5 / 8$ & $7 / 8$ \\
\hline Fibrosis score & $1 / 4$ & $0-1 / 4$ & $2 / 4$ \\
\hline Revised International Autoimmune Hepatitis (AIH) Group Score & 6 & 4 & 18 \\
\hline Definite diagnosis & Obesity related & Obesity related & Obesity+AlH type 1 \\
\hline Follow-up period (months) & 22 & 30 & 21 \\
\hline
\end{tabular}

Total cholesterol levels were $>200 \mathrm{mg} / \mathrm{dl}$ in 9 children and triglyceride levels were $>150 \mathrm{mg} / \mathrm{dl}$ in 15 children, LDL levels were $>150 \mathrm{mg} / \mathrm{dl}$ in 2 patients, HDL levels were $<40 \mathrm{mg} / \mathrm{dl}$ in 9 patients.

Alpha-1 antitrypsin deficiency was found only in 1 (1.4\%) patient and he was diagnosed heterozygotes of the $\mathrm{PiMZ}$ phenotype.

At presentation, all patients were negative for LKM-1 and ASMA, only 3 (4.3\%) patients had ANA positivity. They all had normal ESR, CRP, and IgG levels at presentation. The demographic characteristics of the 3 patients with ANA positivity were given in Table I.

Abdominal ultrasonography revealed hepatomegaly in $76.3 \%$, splenomegaly in $10.5 \%$ and sludge in gallbladder in $5.2 \%$ of the patients.

Ursodeoxycholic acid treatment was given to $44.7 \%$ of the patients. On follow-up, none of the patients had weight control, but normalization of transaminases was achieved in 31 (44.2\%) patients at mean $6.1 \pm 4.6$ (2-19) months. The normalization of ALT wasn't related to ALT levels at presentation and ursodeoxycholic acid treatment ( $p>0.05, p>0.05$ respectively).

Only 3 patients had a liver biopsy due to the persistence of ANA positivity and hypertransaminasemia. The timing of biopsy, ALT, AST, IgG, ESR, CRP levels, ANA titers and the follow-up period of the patients were given in Table II. 
Liver biopsy revealed macrovesicular dominant mixed type steatosis in patient 1 and 2. The liver copper content was negative in both and there was no increment in ESR, IgG and CRP levels at the time of biopsy and on follow-up. Even they didn't lose weight, transaminase levels became normal and ANA was undetectable on follow-up (Table II).

At the time of biopsy, only the $3^{\text {rd }}$ patient had elevated lgG, ESR, CRP levels and high titer ANA (Table II). The liver biopsy revealed macrovesicular dominant mixed type steatosis, mildmoderate dilation of portal areas, mononuclear lymphocyte inflammation and multifocal portal parenchymal limiting plate irregularity, mild increased fibrous tissue and rare plasma cell infiltration in portal areas. The liver copper content was negative. She diagnosed AlH type 1, treated with prednisolone $(40 \mathrm{mg} /$ day) and azathioprine (100 mg/day). At the first month of the treatment, her laboratory findings revealed ALT $81 \mathrm{IU} / \mathrm{L}$, AST 36 $\mathrm{IU} / \mathrm{L}$, ESR $32 \mathrm{~mm} /$ hour, CRP (-) and lgG as $1350 \mathrm{mg} / \mathrm{dl}$. At the $6^{\text {th }}$ month of treatment, transaminases were in normal ranges. During the subsequent 21 months, she remained morbid obese, ALT and AST levels were generally lower than 1.5xULN and ESR, CRP and IgG levels were within normal ranges, ANA titers decreased gradually.

\section{DISCUSSION}

Non-alcoholic fatty liver disease becomes the most common cause of chronic hepatitis due to the increasing prevalence of obesity. It may progress to liver cirrhosis in adult age and it is frequently associated with metabolic syndrome, an obesityrelated disorder. In non-obese children, NAFLD may be related to chronic viral hepatitis, metabolic disease, Wilson's disease, autoimmune disease, and drugs. Also, it is well known that all these diseases may progress to cirrhosis (5). Perhaps an accompanying undiagnosed liver disease may contribute to cirrhosis development in NAFLD patients.

In our study, we aimed to determine whether there was a co-existing liver disease in obese and overweight children with NAFLD. We demonstrated one patient had heterozygote PiMZ phenotype, 3 patients had ANA positivity but only one of them diagnosed $\mathrm{AlH}$.

It was previously reported that PiMZ heterozygous phenotype was related to liver enzyme abnormalities mainly in the first 6 months of life (6). In an adult study, the PiMZ phenotype was found an independent risk factor for the development of liver cirrhosis beyond the main causes such as chronic viral hepatitis (7). In our study, screening for alpha-1 antitrypsin deficiency revealed low levels in one patient with PiMZ heterozygous phenotyped which may be a risk factor for NAFLD related liver fibrosis in adult life.

In adults with NAFLD, antinuclear antibodies (ANA) are occasionally detected, but the significance of ANA remains controversial (8-13). The prevalence of ANA in NAFLD is reported to be $12-46 \%$, higher than the general population $(1,8-13)$, predominately in females $(9,12,14)$. Loria P. et al. (8) suggested that ANA positivity was an accompanying feature of insulin resistance, not an index of primary autoimmune disease. Host's dietary triglycerides enhance adipose tissue or monocyte production of proinflammatory cytokines (such as tumour necrosis factor alpha and interleukin-6) might promote liver injury, and/or trigger the production of autoantibodies such as ANA in steatohepatitis $(8,15)$. On the other hand, ANA is one of the characteristic parameters in AlH. Liver biopsy is required to rule out $\mathrm{AlH}$ in most NAFLD patients with positive ANA because AlH scoring system was found to be insufficient without liver biopsy in adults $(11,13,14,16)$. In different studies, $0.5-8 \%$ of NAFLD patients with positive autoantibodies was diagnosed with definite AlH after liver biopsy $(9,10)$. In our study, ANA positivity was $4.3 \%$, and of the children with NAFLD, AlH diagnosed in $1.4 \%$.

Liver histology is rarely used to diagnose NAFLD in children, blood tests and ultrasonography are used as screening tools (1). But liver biopsy should be performed to diagnose $\mathrm{AlH}$ (5). Due to both follow-up and treatment of NAFLD and AlH differs significantly, the timing of liver biopsy is important in children with NAFLD and ANA positivity.

We performed liver biopsy in 3 overweight/obese girls with NAFLD and ANA positivity on follow-up. Despite all of them had normal serum IgG and ESR levels at presentation, the $3^{\text {rd }}$ patient with high ANA titers at presentation, had an increment in IgG, CRP and ESR levels on the $12^{\text {th }}$ month of follow-up. She diagnosed AlH with the support of liver biopsy, and a significant laboratory improvement was seen under corticosteroid treatment. This good response strengthened the diagnosis of AlH. So IgG and ESR levels might be helpful to screen AiH, in children with ANA positive NAFLD. Similarly, limited number of adult patients with NAFLD, type 2 diabetes mellitus and AlH were reported the effect of corticosteroid treatment and the importance of IgG and ANA titer follow-up $(17,18)$. While thinking of the side effects of prednisolone treatment, no serious adverse event was seen in our patient despite her severe comorbidities.

The association of ANA positivity and histopathological findings of steatohepatitis is also controversial. A significant relation between ANA positivity and high fibrotic stage and necroinflammatory grade was demonstrated in some studies $(9,11)$, while others found no relation $(8,10,12,14)$. In our study, $3^{\text {rd }}$ case who was diagnosed $\mathrm{AlH}$ with high ANA titers had higher fibrotic stage in liver biopsy compared to others.

Another important issue in children with NAFLD is screening the immunization status for hepatitis A and B. It is strongly recommended if no prior vaccination was received (4).

The main limitations of the study are being a retrospective study, and not following the patients with NAFLD for autoantibodies on follow up. 


\section{CONCLUSION}

Especially the obese/overweight children who had NAFLD should be screened for other causes of chronic hepatitis and the development of autoimmune hepatitis should be kept in mind in the presence of ANA.

\section{Compliance with Ethical Standards:}

Conflict of Interest: On behalf of all authors, the corresponding author states that there is no conflict of interest.

Ethical approval: All procedures performed in studies involving human participants were in accordance with the ethical standards of the institutional and/or national research committee and with the 1964 Helsinki declaration and its later amendments or comparable ethical standards.

Informed consent: Informed consent was obtained from all individual participants included in the study.

\section{REFERENCES}

1. Berardis S, Sokal E. Pediatric non-alcoholic fatty liver disease: an increasing public health issue. Eur J Pediatr 2014; 173: 131-9.

2. Middleton JP, Wiener RC, Barnes BH, Gurka MJ, DeBoer MD. Clinical features of pediatric nonalcoholic fatty liver disease: a need for increased awareness and a consensus for screening. Clin Pediatr (Phila) 2014; 53: 1318-25.

3. Sharma A, Freese DK, Chandan V, Zarroug AE, Swain JM, Kumar S. Hepatic cirrhosis secondary to nonalcoholic fatty liver disease in a 12-year-old girl with morbid obesity. Clin Pediatr (Phila) 2014; 53 : 86-8.

4. Vos MB, Abrams SH, Barlow SE, Caprio S, Daniels SR, Kohli R et al. NASPGHAN clinical practice guideline for the diagnosis and treatment of nonalcoholic fatty liver disease in children: recommendations from the expert committee on NAFLD (ECON) and the North American Society of Pediatric Gastroenterology, Hepatology and Nutrition (NASPGHAN). J Pediatr Gastroenterol Nutr 2017; 64: 319-34.

5. Mann JP, Valenti L, Scorletti E, Byrne CD, Nobili V. Nonalcoholic fatty liver disease in children. Semin Liver Dis 2018;38:1-13.

6. Pittschieler K. Liver involvement in alpha1-antitrypsin-deficient phenotypes PiSZ and PiMZ. Acta Pædiatr 2002; 91: 239-40.
7. Gorska K, Korczynski P, Struniawski R, Krenke R, OldakowskaJedynak U, Grabczak EM et al. Heterozygous alpha-1 antitrypsin deficiency in liver transplant candidates. Pol Arch Med Wewn 2013; 123: 14-20.

8. Loria P, Lonardo A, Leonardi F, Fontana C, Carulli L, Verrone AM et al. Non-organ-specific autoantibodies in nonalcoholic fatty liver disease: prevalence and correlates. Dig Dis Sci 2003; 48: 217381.

9. Niwa H, Sasaki M, Haratake J, Kasai T, Katayanagi K, Kurumaya $H$, Masuda $S$ et al. Clinicopathological significance of antinuclear antibodies in non-alcoholic steatohepatitis. Hepatol Res 2007; 37: 923-31.

10. Vuppalanchi R, Gould RJ, Wilson LA, Unalp-Arida A, Cummings $\mathrm{OW}$, Chalasani $\mathrm{N}$ et al. Clinical significance of serum autoantibodies in patients with NAFLD: results from the nonalcoholic steatohepatitis clinical research network. Hepatol Int 2012; 6: 379-85.

11. Adams $L A$, Lindor KD, Angulo P. The prevalence of autoantibodies and autoimmune hepatitis in patients with nonalcoholic fatty liver disease. Am J Gastroenterol 2004; 99: 1316-20.

12. Cotler SJ, Kanji K, Keshavarzian A, Jensen DM, Jakate S. Prevalence and significance of autoantibodies in patients with non-alcoholic steatohepatitis. J Clin Gastroenterol 2004;38:801-4.

13. Ravi S, Shoreibah M, Raff E, Bloomer J, Kakati D, Rasheed K et al. Autoimmune Markers Do Not Impact Clinical Presentation or Natural History of Steatohepatitis-Related Liver Disease. Dig Dis Sci 2015; 60: 3788-93.

14. Yatsuji S, Hashimoto E, Kaneda H, Taniai M, Tokushige K, Shiratori K. Diagnosing autoimmune hepatitis in nonalcoholic fatty liver disease: is the International Autoimmune Hepatitis Group scoring system useful? J Gastroenterol 2005; 40: 1130-8.

15. Tsuneyama K, Baba H, Kikuchi K, Nishida T, Nomoto K, Hayashi $S$ et al. Autoimmune features in metabolic liver disease: a singlecenter experience and review of the literature. Clin Rev Allergy Immunol 2013; 45: 143-8.

16.Weiler-Normann C, Lohse A.W. Nonalcoholic fatty liver disease in patients with autoimmune hepatitis: further reason for teeth GNASHing? Dig Dis Sci 2016; 61; 2462-4.

17.Komura T, Ohta H, Seike T, Shimizu Y, Nakai R, Omura H, et al. The efficacy of corticosteroid therapy in a patient with non-alcoholic steatohepatitis overlapping autoimmune hepatitis. Intern Med 2018;57:807-12.

18.Fukuda S, Komori A, Itoh M, Mihara Y, Hashimoto S, Bae SK, et al. Histological remission during corticosteroid therapy of overlapping nonalcoholic steatohepatitis and autoimmune hepatitis: Case report and literature review. Case Rep Gastroenterol 2011;5:553-7. 